\title{
Spatial heterogeneity in the distribution of plants and benthic invertebrates in the lagoon of Orbetello (Italy)
}

\section{Hétérogénéité spatiale dans la distribution des plantes et des invertébrés benthiques de la lagune d'Orbetello (Italie)}

\author{
Anna Maria De Biasi ${ }^{\mathrm{a}, \mathrm{b}, *}$, Lisandro Benedetti-Cecchi ${ }^{\mathrm{b}}$, Lorenzo Pacciardi ${ }^{\mathrm{a}}$, Elena Maggi ${ }^{\mathrm{b}}$, \\ Stefano Vaselli ${ }^{\mathrm{b}}$, Iacopo Bertocci ${ }^{\mathrm{b}}$ \\ ${ }^{a}$ Centro Interuniversitario di Biologia Marina ed Ecologia Applicata, via N. Sauro 4, 57127 Livorno, Italy \\ ${ }^{b}$ Dipartimento di Scienze dell'Uomo e dell'Ambiente, Via A. Volta 6, 56126 Pisa, Italy
}

Received 31 July 2002; accepted 30 September 2002

\begin{abstract}
Many studies in marine coastal lagoons have focused on the marine-to-terrestrial gradient as a main source of variation for the structure of assemblages. In this paper, the magnitude of differences among locations arranged along the marine-to-terrestrial gradient of the western lagoon of Orbetello (Grosseto, Italy) was contrasted with the amount of spatial variability occurring among sets of locations that were not positioned along this axis. We propose that if the most important processes influencing assemblages were those associated with the external-internal gradient of the lagoon, as usually supposed, then assemblages should differ more among these locations than among any other locations. To test the above proposition, four locations arranged along the two major axes of the lagoon were established in November 2000. Each location was sampled three times (November 2000, April 2001, August 2001) to test for temporal consistency in spatial patterns. At each time of sampling, three replicate sites were established in each location. This design enabled estimates of spatial variability to be obtained at three scales: among locations hundreds of meters apart, among sites tens of meters apart and among quadrats hundreds of centimeters apart. Non-metric multidimensional scaling (nMDS) ordination plots on abundance data revealed differences among assemblages hundreds of meters apart. Assemblages in the inner part of the lagoon were separated from those closer to the sea inlet, depending on the marine-to-terrestrial gradient. In addition to this pattern, differences also occurred among assemblages hundreds of meters apart, but positioned at a similar distance from the sea. Multifactorial Anovas on abundance of the most common taxa showed significant differences in mean values at the scales of location and site, with patterns changing over time. These results indicated that spatial structure in assemblages was not a distinctive feature of locations arranged along the marine-to-terrestrial gradient in the lagoon of Orbetello. Similar differences also occurred among other sets of locations at the scale of hundreds of meters, regardless of their position in the lagoon.
\end{abstract}

(C) 2003 Éditions scientifiques et médicales Elsevier SAS and Ifremer/CNRS/IRD. All rights reserved.

\section{Résumé}

Beaucoup de recherches sur les lagunes côtières se sont focalisées sur le gradient terre-mer comme principale source de variation de la structure des assemblages. Dans cet article, l'importance des différences d'un lieu à l'autre le long d'un tel gradient dans la partie ouest de la lagune d'Orbetello (Grosseto, Italie) est comparée avec l'importance de la variabilité spatiale de sites qui ne sont pas situés sur cet axe. Si l'influence dominante était bien liée à ce gradient interne-externe, les assemblages devraient différer plus nettement au sein de ces lieux, comparé à tout autre lieu. Pour tester cette proposition, quatre lieux le long des deux axes majeurs de la lagune ont été échantillonnés à trois reprises : novembre 2000, avril 2001 et août 2001. À chaque sortie, trois sites-répliques ont été établis pour chaque lieu. Cette stratégie permet d'estimer la variabilité spatiale à trois échelles : au sein des lieux à des distances de 100 mètres, au sein des sites à des distances de 10 mètres et au sein des quadrats à des distances d'un mètre. Des diagrammes d'abondance classés suivant une échelle multidimensionnelle non métrique

\footnotetext{
* Corresponding author.

E-mail address: a.debiasi@cibm.it (A.M. De Biasi).
} 
révèlent des différences au sein des assemblages distants de centaines de mètres. Les assemblages dans la partie intérieure de la lagune sont séparés de ceux plus près du grau, en accord avec le gradient terre-mer. À côté de ce schéma, des différences apparaissent également parmi les assemblages distants de plusieurs centaines de mètres mais situés à une même distance de la mer. Une analyse multifactorielle utilisant le test Anovas sur l'abondance des taxons les plus fréquents montre des différences significatives des valeurs moyennes aux échelles du lieu et du site, avec des schémas d'organisation variant au cours du temps. Ces résultats montrent que la structure spatiale des assemblages n'est pas un trait caractéristique des lieux bâti autour du terre-mer dans la lagune d'Orbetello. Des différences similaires se rencontrent également parmi les autres ensembles de lieux à l'échelle des centaines de mètres, ceci dépendant de leur position dans la lagune.

(C) 2003 Éditions scientifiques et médicales Elsevier SAS and Ifremer/CNRS/IRD. Tous droits réservés.

Keywords: Spatial heterogeneity; Phytozoobenthos; Coastal lagoon; Western Mediterranean

Mots clés : Hétérogénéité spatiale ; Phyto- et zoo-benthos ; Lagune côtière ; Méditerranée occidentale

\section{Introduction}

The notion that coastal lagoons represent unpredictable aquatic systems because of wide fluctuations in abiotic variables is widely appreciated in the scientific literature (Wilke, 1998).

The ecological characterisation of these environments has been largely debated and no general consensus has emerged among ecologists, in part as a consequence of this variability. Some authors considered these habitats as distinct 'bioecological domains', characterised by 'stable communities' (Remane, 1940; Bacci, 1954) while others (Alee et al., 1949) considered coastal lagoons as an ecotone between the sea and inland waters with characteristics intermediate between these two adjacent habitats.

Later, Guelorget and Perthuisot (1982, 1983, 1992, hereafter referred to as GP) proposed a new definition of aquatic ecosystems between marine and continental waters and considered them together as an autonomous ecological domain called paralic domain.

Despite divergent points of view (Wilke, 1998; Pérès and Picard, 1964; GP, 1983; Petit, 1953, 1962; D'Ancona and Battaglia, 1962; Sacchi and Occhipinti-Ambrogi, 1992) among scientists about the definition of coastal lagoons, most ecologists agreed that the marine-to-terrestrial gradient explained most of the variations in patterns of distribution of benthic species. According to this model, clear patterns of zonation of assemblages should exist along the sea-land axes.

It was traditionally accepted that salinity, strictly related to the increasing distance from the communication link with the sea, was the main factor involved in determining this gradient and hence the spatial distribution of benthic organisms (Remane and Schlieper, 1956; Petit, 1962; Sacchi, 1967; Vatova, 1963).

In the GP model, salinity was incorporated into the confinement concept. This is the lack of 'vital elements' of marine origin at a given point of the paralic environment that is a function of the time taken by the water coming from the sea to reach that point.

All these models, despite their intrinsic differences, provided an attempt to relate abiotic gradients with distributional patterns of benthic assemblages. These approaches were essentially descriptive and inadequate to describe, let alone to explain, the natural temporal and spatial variability of biological assemblages in lagoons. A major flaw of several studies comparing assemblages along the marine-toterrestrial gradient was that sampling was done at single points along this main axis, confounding effects due to the gradient with other sources of spatial variation in assemblages. To guarantee representative sampling, replicate sites must be sampled at each point along the gradient (Hurlbert, 1984).

Many studies have shown or suggested that spatial and temporal heterogeneity (patchiness) is an intrinsic feature of many marine benthic assemblages (Morrisey et al., 1992a, b; Metaxas et al., 1994; Kennelly and Underwood, 1992; Underwood et al., 1991; Underwood and Chapman, 1996; Underwood and Skilleter, 1996; Archambault and Bourget, 1998; Benedetti Cecchi et al., 1998; Burrows and Hawkins, 1998). This variation must be considered in models describing the structure of assemblages to avoid undue generalisations and to assist in identifying likely causal processes responsible for the observed patterns (Dunstan and Johston, 1998; Blanchard and Bourget, 1999).

The main objective of this study was to test hypotheses about spatial and temporal patterns in assemblages of plants and benthic invertebrates in the western part of lagoon of Orbetello (Grosseto, Italy). Patterns of variation in distribution and abundance of organisms across the marine-toterrestrial gradient were contrasted with alternative patterns that might occur along axes not related to the increasing distance from the sea inlets. We proposed that if the most important processes influencing assemblages were those associated with the external-internal gradient of the lagoon, as usually supposed, then there should be more variations among locations arranged along this gradient than among any other set of locations. Furthermore, there should also be more variations over large than small spatial scales. These hypotheses have already been examined in a previous study that focused on assemblages living on artificial substrata in the lagoon of Orbetello (Benedetti-Cecchi et al., 2001). Here, we extend this analysis to assemblages living on the natural, soft bottom substratum of the lagoon. 


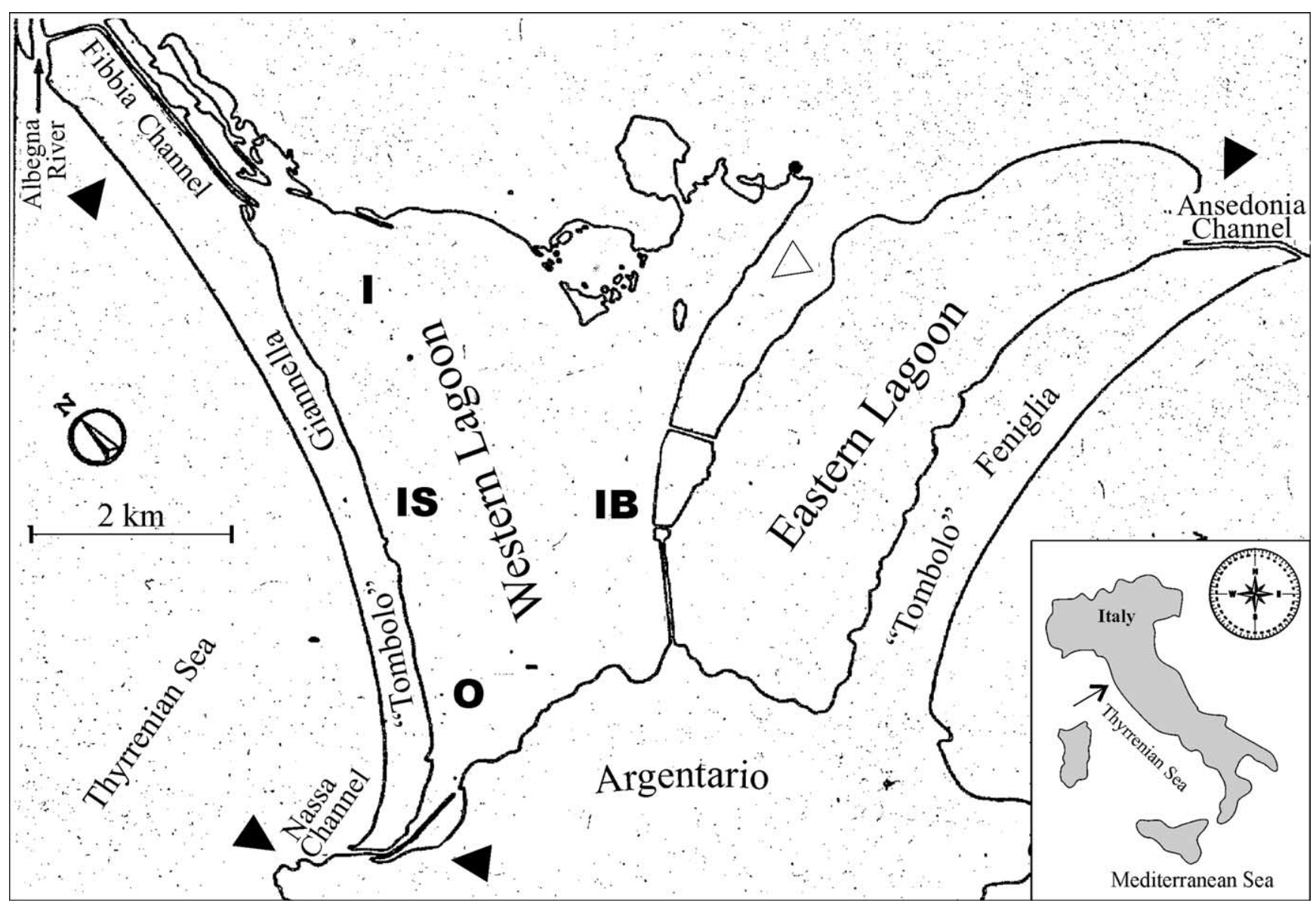

Fig. 1. Study area. Locations are indicated by letters $(\mathrm{O}=$ Outer, $\mathrm{IS}=$ Intermediate sea-side, $\mathrm{IB}=$ Intermediate Bridge-side, $\mathrm{I}=\mathrm{Inner})$. Triangles indicate pollution waste: black = aquaculture; white = urban (from Lenzi et al., 1998 modified).

\section{Methods}

\subsection{Study area}

The Orbetello lagoon, one of the widest Western Mediterranean poly-hypersaline basins, lies between the coast and Mount Argentario in southern Tuscany. It is separated from the sea by two spits or "Tombolos", a third incomplete spit, on which the town of Orbetello (Grosseto) is located, is connected with Mount Argentario by a causeway that divides the lagoon into the eastern and the western basin. The eastern lagoon is linked to the Tyrrenian Sea by the Ansedonia Channel and the western basin by the Nassa Channel. Additionally, seawater input is guaranteed by a pumping system realised in 1982. Through the Fibbia Channel, the western basin occasionally receives freshwater from the Albegna river Fig. 1. The lagoon, with an average depth of $1 \mathrm{~m}$, is characterised by silty sediments located in the deeper central part and by fine sediments near the sea mouth.

In the last 25 years, development of human activities along the lagoon perimeter has produced sensitive changes in the environment leading to eutrophication (Lenzi et al., 1998), alteration of shores and acceleration of the filling-up process (Lenzi, 1992). There are many different sources of eutrophication: from tourism that causes a high increase of urban waste (119 tonne per year of nitrogen and 24 tonne per year of phosphorus) to intensive aquaculture that in the last 15 years greatly affected the nutrient waste ( 37 tonne per year of nitrogen and 1.2 tonne per year of phosphorus). The distribution of these pollution sources is reported in Fig. 1

The lagoon is characterised by high temporal variation in physical-chemical properties that experience extreme values for long periods particularly in spring and summer. In fact, the lagoon in some years suffered severe crises of anoxia due to the blooming and subsequent decay of algal masses (Lenzi, 1992; Lardicci et al., 1997; Lardicci and Rossi, 1998). Some measures have been adopted to limit the eutrophication such as harvesting of the floating sea-weed biomass, but only a small quantity of the yielded standing crop was removed (less than 10\%). Our study was carried out on the western side of the lagoon.

\subsection{Sampling design}

A three-factor sampling design was used to assess spatial and temporal variations in the distribution of plants and benthic invertebrates in the lagoon. The largest spatial scale was provided by four locations $(\mathrm{O}=$ outer, $\mathrm{I}=$ inner, $\mathrm{IB}=$ intermediate bridge-side, IS = intermediate sea-side) distributed along the two major axes of the lagoon and located 
hundreds of meters apart Fig. 1]. Three sites 10s of meters apart were established within each location and three replicate samples were collected a few meters apart within each site.

To assess whether spatial patterns were consistent over time, sampling was repeated three times (November 2000; April 2001; August 2001). New sites were established at each location at each time of sampling.

Each sampling unit was chosen randomly by dropping a quadrate $(50 \times 50 \mathrm{~cm})$ from the boat. The bottom was scrapped and the fronds and the animals were raked from the sample unit and placed in plastic bags. In the laboratory, the samples were sieved through a $1 \mathrm{~mm}$ mesh and fixed in buffered formalin (5\%). Then the samples were sorted and, whenever possible, the fauna and the flora were identified to species level. All the animals were counted, whereas the abundance of algae and seagrasses was expressed as wet weight. Algae formed intricate mats where red corticated species (mostly Gracilaria verrucosa) and green filamentous species (mostly Chaetomorpha aerea) were most abundant. It was difficult to separate species from these mats, so biomass estimates usually refer to a mixture of algae. Phanerogams, in contrast, were weighted separately. The benthic fauna was sorted and counted to obtain estimates of species abundance.

\subsection{Data analysis}

If the external-internal gradient of the lagoon drives much of the variation in assemblages, then one would expect differences among O, IS and I, but not between IS and IB, since the latter are located at a similar distance from the sea Fig. 1. In this case, IB would also differ from both $\mathrm{O}$ and I. In contrast, if other sources of variation are important, either in addition or as an alternative to the external-internal gradient, then one would expect differences between IS and IB. These hypotheses were tested using univariate and multivariate techniques. Non-parametric multivariate techniques were carried out using the Primer statistical software package to perform analyses of the abundance data (see Clarke and Warwick, 1994 for a full description). A matrix of similarity was obtained among every pair of sites (using an 'average' sample per site) using the Bray-Curtis index of similarity on fourth root transformed data. Non-metric multidimensional scaling (nMDS) was used to produce two-dimensional ordinations of the rank orders of similarities of the 'average' samples. Formal significance tests for differences among locations and among sites were performed using two-way nested Anosim randomisation/permutation tests. Simper was used to determine which taxa contributed most to the dissimilarity among locations (Clarke, 1993). The contribution of each species to the Bray-Curtis measure was calculated on fourth root transformed data and the species ranked depending on their contribution in discriminating among groups (Warwick and Clarke, 1991).

Analysis of variance (Anova) was used to test hypotheses about spatial and temporal patterns in the distribution of those species that contributed most in discriminating among locations. The analysis was a three-factor Anova with time (random, orthogonal to location, three levels), location (fixed, orthogonal to time, four levels) and site (random, nested in location $\mathrm{x}$ time interaction, three levels), as factors. The assumption of homogeneity of variances was checked by Cochran's test and, when necessary, data were transformed (Underwood, 1997).

\section{Results}

A total of 141,213 organisms belonging to 44 species or higher taxa were collected in the three sampling dates. It was impossible to identify at species level all the organisms because of their very high abundance. For some taxa (e.g. amphipoda), estimates of the most widespread species were done. In such cases, we prefer to run the statistical analyses using a higher taxonomic level rather than an imprecise quantitative estimate at a more accurate taxonomic resolution.

The most abundant taxon was the amphipods $(86,624$ individuals) which account for over $60 \%$ of the total abundance. Among them, Corophium insidiosum, a species typical of brackish environments, and Gammarus aequicauda, a species linked to algal cover, were the most abundant and widespread. The other classes of crustaceans (tanaidaceans, isopods, decapods) represented only $14 \%$ of the total abundance. Among the molluscans (1.3\% of the total abundance), Gibbula richardi was the most important species.

Actiniaria (14,344 individuals) and polychaeta (7514 individuals) were found abundantly as well. They account for $10 \%$ and $5.3 \%$ of the total abundance, respectively. In addition, 5604 organisms of Chironomus salinarius were collected.

nMDS ordination plots repeated at each time of sampling revealed considerable differences in structure of assemblages among locations, over a scale of hundreds of meters. Data from November 2000 are reported here as an illustrative example Fig. 2, but patterns for other times of sampling were similar. Locations $\mathrm{O}$ and IS were arranged on the left hand side of the nMDS plane. They were clearly separated from locations IB and I positioned on the opposite side. Location I-in the inner part of the lagoon-separated from location $\mathrm{O}-$ was closer to the sea inlet, depending on the marine-terrestrial gradient. In addition, locations IB and IS, positioned at a similar distance from the sea, segregated on opposite side in the nMDS plot, suggesting the existence of other relevant sources of variation Fig. 2.

Two-way nested Anosim detected significant differences among locations and among sites within locations Table 1. Pairwise comparisons indicated significant differences among any pair of locations, with the exception of O vs. IS that did not differ significantly.

Simper revealed differences in dissimilarities among locations in the range 32.9-42.0\%, with maximum and minimum dissimilarities occurring between IB and $\mathrm{O}$ and between IB 


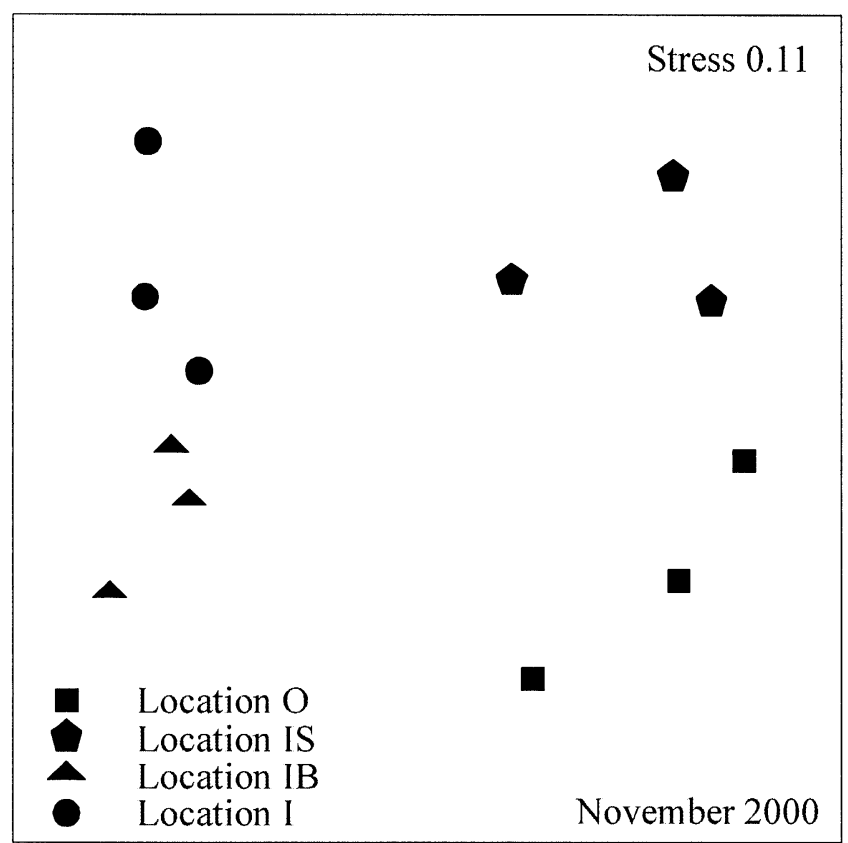

Fig. 2. nMDS ordination plot on abundance matrix. Data were doublesquare root transformed. Data were from November 2000. Each point referred to a single site (averaged replicates).

and I, respectively. The results of Simper analysis for each location regarding the first sampling date are shown in Table 2 Taxa are reported depending on their average contribution to dissimilarity between locations. The species list has been cut off when the cumulative contribution to the dissimilarity reached $40 \%$. The taxa having the greatest contribution to $40 \%$ dissimilarity between the Bray-Curtis cluster were generally the most abundant. Among them, Zostera noltii, algae, Ophiuridae, and Sphaeromatidae showed a contribution of about $10 \%$. The contribution of the other taxa never exceeded $6.4 \%$.

Z. noltii discriminated more between locations IS vs. IB than between any other pair of locations. Location O supported the largest biomass of the macroalgae that discriminated between IS and either location I or O. Ophiurans discriminated most between IB and I than between any other pair of locations. However, these observations are not consistent over time.

Table 1

Two-way nested ANOSIM. Values of $R$ for global test between locations and between sites and results of pairwise test

\begin{tabular}{lll}
\hline Global test & \multicolumn{2}{l}{ Pairwise test } \\
\cline { 2 - 3 } & Location & $R$ \\
\hline Global $R$ (locations) $=0.765^{* *}$ & (I, IB) & $0.963^{*}$ \\
Global $R$ (sites) $=0.568^{* *}$ & (I, IS) & $1.000^{*}$ \\
& (I, O) & $1.000^{*}$ \\
& (IB, IS) & $0.815^{*}$ \\
& (IB, O) & $0.852^{*}$ \\
& (IS, O) & 0.074 \\
\hline
\end{tabular}

$* P<0.05$. ** $P<0.01$.
Table 2

SIMPER analysis results. Dissimilarity percentages between locations and contribution to the average dissimilarity of the single species. Cut off at $40 \%$ of cumulative percentage. Percent $=$ percentage of dissimilarity contribution

\begin{tabular}{lc}
\hline Species & Percent \\
\hline Locations O vs. IB (avg dissimilarity = 42.06) & \\
Zoostera noltii & 9.00 \\
Ophiuridae & 7.88 \\
Algae & 6.72 \\
Gibbula richardi & 6.41 \\
Sphaeromatidae & 4.75 \\
Amphipoda & 4.04 \\
Locations O vs. IS (avg dissimilarity = 40.21) & \\
Ophiuridae & 10.38 \\
Algae & 9.39 \\
Chironomus salinarius & 5.10 \\
Amphipoda & 4.67 \\
Gibbula richardi & 4.45 \\
Haminoea navicula & 4.08 \\
Locations IS vs. IB (avg dissimilarity = 39.78) & \\
Algae & 12.61 \\
Zoostera noltii & 11.31 \\
Chironomus salinarius & 7.77 \\
Sphaeromatidae & 5.37 \\
Locations O vs. I (avg dissimilarity = 41.88) & \\
Ophiuridae & 8.49 \\
Zoostera noltii & 7.62 \\
Actiniaria & 7.09 \\
Gibbula richardi & 6.91 \\
Algae & 5.22 \\
Haminoea navicula & 5.12 \\
Locations IB vs. I (avg dissimilarity = 32.92) & 5.11 \\
Sphaeromatidae & \\
Serpulidae & 3.93 \\
Polychaeta & \\
Actiniaria & \\
Amphipoda & 6.32 \\
Locations IS vs. I (avg dissimilarity = 41.72) & 5.89 \\
Algae & 5.73 \\
Zoostera noltii & 5.26 \\
Amphipoda & \\
Chironomus salinarius & \\
Actiniaria & \\
Serpulidae & \\
\hline & \\
&
\end{tabular}

Zostera noltii abundance and distribution showed high variability over the three sampling dates. The highest values were observed in August 2002 [Fig. 3.

Macroalgae were generally abundant in the outer part of the lagoon all over the study period reaching their maximum in April 2002 Fig. 3.

Ophiurans were very abundant close to the sea inlet, whereas they were almost absent at the other locations during the first and the second sampling dates. In August 2002, they strongly increased and they were mostly abundant in the inner part of the lagoon Fig. 3 .

In contrast, Sphaeromatidae were more abundant in the first than in the other sampling dates. They colonised all over the lagoon with slight differences in abundance among loca- 

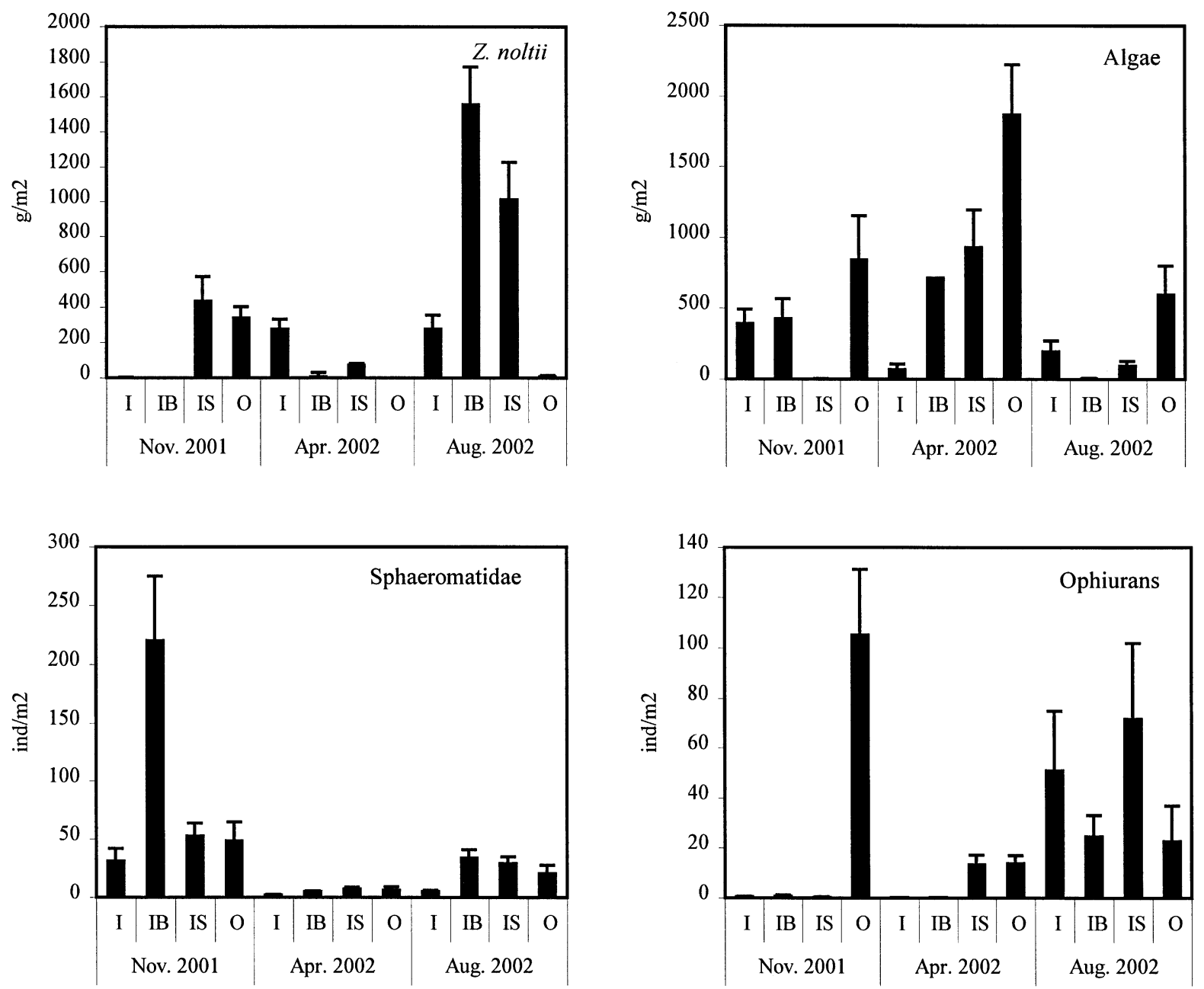

Fig. 3. Mean biomass (Z. noltii and algae) and abundance (Ophiuridae and Sphaeromatidae) of the most important taxa contributing to the percentage dissimilarity among locations. Bars indicate standard error $(n=15)$; data are from November 2000, April 2001 and August 2001.

tions. The only exception was observed in November 2001 relative to IB where they reached their maximum Fig. 3.

Analysis of variance on the most common taxa showed significant differences in mean abundance at the scales of location and site, with patterns changing over time at the largest spatial scale. The analysis on Sphaeromatidae is shown as an illustrative example Table 3). This analysis detected a highly significant time $\mathrm{x}$ location interaction, in addition to significant spatial variation at the scale of sites. A summary of significant results is shown for the other taxa Table 4.

Table 3

Analysis of variance on abundance data of Sphaeromatidae

\begin{tabular}{lcrrr}
\hline Source of variation & \multicolumn{4}{l}{ Sphaeromatidae } \\
\cline { 2 - 5 } & \multicolumn{1}{l}{ df } & \multicolumn{1}{l}{ MS } & $P$-level \\
\hline Time $=\mathrm{T}$ & 2 & 115536.80 & 12.54 & 0.0002 \\
Location $=\mathrm{L}$ & 3 & 48142.70 & 1.34 & 0.3468 \\
$\mathrm{~T} \times \mathrm{L}$ & 6 & 35926.27 & 3.90 & 0.0074 \\
Site $(\mathrm{T} \times \mathrm{L})$ & 24 & 9216.57 & 2.42 & 0.0007 \\
Residual & 144 & 3810.46 & & \\
\hline Cochran's $C$ test $=0.61 . P<0.05$. No trasformation.
\end{tabular}

\section{Conclusions}

The results of this study do not support the hypothesis that patterns of distribution and abundance of organisms in the western part of the lagoon of Orbetello are related only to the marine-to-terrestrial gradient. Our investigation showed that, on average, dissimilarity between assemblages did not vary only as a function of distance from the sea inlet. In fact, differences between assemblages located on the opposite side of the sea-land axes (O vs. I) were not larger than those among any other set of locations.

Table 4

Summary of analysis of variance on the most abundance taxa. For degrees of freedom and $F$-ratio, see Table 3

\begin{tabular}{llllll}
\hline $\begin{array}{l}\text { Source of } \\
\text { variation }\end{array}$ & Z. noltii & Algae & Ophiurans & C. salinarius & Idothea $\mathrm{sp}$. \\
\hline Time $=\mathrm{T}$ & $*$ & $\mathrm{~ns}$ & $\mathrm{~ns}$ & $*$ & $\mathrm{~ns}$ \\
Location $=\mathrm{L}$ & $\mathrm{ns}$ & $\mathrm{ns}$ & $\mathrm{ns}$ & $\mathrm{ns}$ & $\mathrm{ns}$ \\
$\mathrm{T} \times \mathrm{L}$ & $*$ & $*$ & $\mathrm{~ns}$ & $*$ & $*$ \\
Site $(\mathrm{T} \times \mathrm{L})$ & $*$ & $*$ & $*$ & $*$ & $*$ \\
\hline$* P<0.05 . \mathrm{ns}=$ not significant. &
\end{tabular}


These results indicated that in addition to processes operating along the marine-terrestrial gradient, other sources of variability are important in maintaining heterogeneous patterns of distribution and abundance of organisms in this lagoon. This interpretation is supported by the existence of statistically significant differences between assemblages situated at similar distance from the sea inlet (IS vs. IB).

The processes that might account for these patterns can only be hypothesised at this stage. Our results, however, indicated that models based on salinity as the main variable influencing patterns of distribution and abundance of organisms in coastal lagoons are too simplistic and should be considered with caution. Similarly, the theory of 'confinement' may not be appropriate to describe spatial pattern in assemblages in every lagoon.

Our analyses provided evidence of spatial variability in structure of benthic assemblages over scales of 10s (sites) to hundreds (locations) of meters. Three main areas can be recognised in the western part of the lagoon of Orbetello (northern, south-western and eastern), where assemblages occur with distinct structures. It is important to note, however, that differences among locations were not consistent through time in univariate analyses. Temporal variability injects additional uncertainty in models that attempt to explain changes in the structure of assemblages as a function of one or a few variables. Differences among locations can be magnified in the presence of temporal variation, but estimates of space $\mathrm{x}$ time interactions are unavailable for most taxa inhabiting coastal lagoons. Appreciation of the inherent variability of these assemblages is likely to enhance our capabilities to understand the underlying causal processes and to provide better models to predict the response of populations to environmental change.

Spatial heterogeneity was recognised by previous authors who worked in the lagoon of Orbetello. Benedetti-Cecchi et al. (2001) identified spatial variations in development of epibenthic assemblages at the scale of hundreds of meters. Similarly, Lardicci et al. (2001) identified considerable spatial variability in abundance and biomass in faunal organisms at the same scale. It is interesting to note that despite a coarse level of taxonomic resolution, our analyses were able to detect significant spatial and temporal patterns for most response variables. Lumping species in higher taxonomic or morphological groups is likely to decrease estimates of variability as a consequence of an 'averaging effect' (Doak et al., 1998). Larger spatial and temporal variations might be expected for estimates of abundance of single species (e.g. Benedetti-Cecchi, 2000).

Although usually a target of basic ecological research, estimation of natural spatial and temporal variation for populations and assemblages has important implications for the design and interpretation of studies of impact or managerial intervention (Underwood, 1996). Identifying spatial patterns in complex habitats such as the lagoon of Orbetello may have important practical implications. Often these habitats are managed as units, with decisions adopted at the scale of the lagoon. Interventions such as the mechanical removal of algae or attempts to mitigate eutrophication through regulation of the amount of water exchanged with the sea are examples. As shown by this and previous studies (Lardicci et al., 2001; Benedetti-Cecchi et al., 2001), the lagoon is not a unique, homogeneous habitat. This raises the possibility that different portions of the lagoon might require different management options, depending on the prevailing processes that operate locally. Identifying the processes that generate and maintain spatial and temporal patchiness of assemblages will be critical to underpin managerial decisions in this complex habitat. Documentation of pattern, as targeted in the present study, is the first step to achieve this objective.

\section{Acknowledgements}

We wish to thank F. Bulleri (University of Pisa, Italy) for scientific suggestions and M. Lenzi (Orbetello) for field assistance.

\section{References}

Alee, W.C., Emerson, A.E., Park, O., Park, T., Schmidt, K.P., 1949. Principles of animal ecology. W.B. Saunders Co, Philadelphia, Pennsylvania.

Archambault, P., Bourget, E., 1998. Scales of coastal heterogeneity and benthic intertidal species richness, diversity and abundance. Mar. Ecol. Prog. Ser. 136, 111-121.

Bacci, G., 1954. Alcuni rilievi sulla fauna di acque salmastre. Pubb. Staz. Zool. Napoli 25 (2), 380-396.

Benedetti-Cecchi, L., 2000. Priority effects, taxonomic resolution, and the prediction of variable patterns of colonization of algae in littoral rock pools. Oecologia 123, 265-274.

Benedetti-Cecchi, L., Airoldi, L., Abbiati, M., Cinelli, F., 1998. Spatial variability in the distribution of sponges and cnidarians in a sub littoral marine cave with sulfur-water springs. J. Mar. Biol. Assoc. UK 78, $43-48$.

Benedetti-Cecchi, L., Rindi, F., Bertocci, I., Bulleri, F., Cinelli, F., 2001. Spatial variation in development of epibenthic assemblages in a coastal lagoon. Est. Coast. Sh. Sc. 52, 659-668.

Blanchard, D., Bourget, E., 1999. Scales of coastal heterogeneity: influence on intertidal community structure. Mar. Ecol. Prog. Ser. 170, 163-173.

Burrows, M.T., Hawkins, S.J., 1998. Modelling patch dynamics on rocky shores using deterministic cellular automata. Mar. Ecol. Prog. Ser. 167, $1-13$.

Clarke, K.R., 1993. Non-parametric multivariate analyses of changes in community structure. Aust. J. Ecol. 18, 117-143.

Clarke, K.R., Warwick, R.M., 1994. Change in Marine Communities: An Approach to Statistical Analysis and Interpretation. Natural Environment Research Council, UK.

D’Ancona, U., Battaglia, B., 1962. La lagune salmastre dell'Alto Adriatico, ambiente di popolamento e di selezione. Pubbl. Staz. Zool. Napoli 32 (Suppl.), 315-335.

Doak, D.F., Bigger, D., Harding, E.K., Marvier, M.A., Omalley, R.E., Thomson, D., 1998. The statistical inevitability of stability-diversity relationships in community ecology. Am. Nat. 151, 264-276.

Dunstan, P.K., Johston, C.R., 1998. Spatio-temporal variation in coral recruitment at different scales on Heron Reef, southern Great Barrier Reef. Coral Reefs 17, 71-81. 
Guelorget, O., Perthuisot, J.P., 1982. Structure et évolution des peuplements benthiques en milieu paralique. Comparison entre un modèle dessalé (Étang du Prévost, France) et un modèle sursalé (La Bahiret el Biba, Tunisie). Conséquences biologiques et géologiques. J. Rech. Océanogr. 7 (2-4), 2-11.

Guelorget, O., Perthuisot, J.P., 1983. Le domaine paralique. Expressions géologiques, biologiques et économiques du confinement. Trav. Lab. Géol. ENS, Paris 16, 1-136.

Guelorget, O., Perthuisot, J.P., 1992. Paralic ecosystems. Biological organization and functioning. Vie Milieu 42 (2), 215-251.

Hurlbert, S.J., 1984. Pseudoreplication and design in ecological field experiments. Ecol. Monogr. 54, 187-211.

Kennelly, S.J., Underwood, A.J., 1992. Fluctuations in the distribution and abundances of species in sublittoral kelp forests in New South Wales. Aust. J. Ecol. 17, 367-382.

Lardicci, C., Rossi, F., Castelli, A., 1997. Analysis of macrozoobenthic community structure after severe dystrophic crises in a Mediterranean coastal lagoon. Mar. Pollut. Bull. 34 (2), 536-547.

Lardicci, C., Rossi, F., 1998. Detection of stress on macrozoobenthos: evaluation of one methods in a coastal Mediterranean lagoon. Mar. Environ. Res. 45 (4-5), 367-386.

Lardicci, C., Como, S., Corti, S., Rossi, F., 2001. Recovery of the macrozoobenthic community structure after severe dystrofic crises in a Mediterranean coastal lagoon (Orbetello Italy). Mar Pollut. Bull. 42 (3), 202-214.

Lenzi, M., 1992. Experiences of management of Orbetello lagoon, eutrophication and fishing. The Science of the total environment (Suppl.), 1189-1198.

Lenzi, M., Costa, A., Gennarini, S., 1998. Variazioni di dominanza nei popolamenti algali della laguna di Orbetello. Un'ipotesi che ne individua le cause. Atti Soc. Tosc. Sc. Nat. 105, 35-45.

Metaxas, A., Hunt, H.L., Scheibling, R.E., 1994. Spatial and temporal variability of macrobenthic communities in tidepools on a rocky shore in Nova Scotia, Canada. Mar. Ecol. Prog. Ser. 105, 89-103.

Morrisey, D.J., Howitt, L., Underwood, A.J., Stark, J.S., 1992a. Spatial variation in soft-sediment benthos. Mar. Ecol. Prog. Ser. 81, 197-204.

Morrisey, D.J., Underwood, A.J., Howitt, L., Stark, J.S., 1992b. Temporal variation in soft-sediment benthos. J. Exp. Mar. Biol. Ecol. 164, 233-245.
Petit, G., 1953. Introduction à l'étude écologique des étangs méditerranéens. Vie Milieu 4, 569-604.

Petit, G., 1962. Quelques considérations sur la biologie des eaux saumâtres méditerranéennes. Pubbl. Staz. Zool., Napoli 32, 205-218.

Pérès, J.M., Picard, J., 1964. Nouveau manuel de bionomie benthique de la mer Méditerranée. Recueil des Travaux de la Station Marine d'Endoume 42, 3-113.

Remane, A., 1940. Einfühg in die zoologische Ökologie der Nord und Ostsee. Tierwelt der Nord und Ostsee.

Remane, A., Schlieper, C., 1956. Die biologie ds Brackwassers. Die Binnengewässer, Stuttgart.

Sacchi, C.F., 1967. Rythmes des facteurs physicochimiques du milieu saumâtre et leur emploi comme indice de production. Problèmes de productivité biologique. Masson, Paris, pp. 131-158.

Sacchi, C.F., Occhipinti Ambrogi, A., 1992. Confinement et biocenoses paraliques. Vie Milieu 42 (2), 207-214.

Underwood, A.J., 1996. Detection, interpretation, prediction and management of environmental disturbances: some roles in marine ecology. J. Exp. Mar. Biol. Ecol. 200, 1-27.

Underwood, A.J., 1997. Experiments in ecology. Their logical design and interpretation using analysis of variance. Cambridge University Press, Cambridge.

Underwood, A.J., Chapman, M.G., 1996. Spatial patterns of distribution on intertidal invertebrates. Oecologia 107, 212-224.

Underwood, A.J., Kingsford, M.J., Andrew, N.L., 1991. Patterns in shallow marine assemblages along the coast of New South Wales. Aust. J. Ecol. 16, 231-249.

Underwood, A.J., Skilleter, G.A., 1996. Effects of patch size on the structure of assemblages in rocky pools. J. Exp. Mar. Biol. Ecol. 197, 63-90.

Vatova, A., 1963. Conditions hydrographiques et productivité dans la lagune moyenne de Venise. Rapp. Comm. Int. Mer Médit. 17 (3), 753-755.

Warwick, R.M., Clarke, K.R., 1991. A comparison of some methods for analysing changes in benthic community structure. J. Mar. Biol. Assoc. UK 71, 225-244.

Wilke, M., 1998. Variabilité des facteurs abiotiques dans les eaux d'une lagune méditerranéenne, l'étang de Canet. Vie Milieu 48 (3), 157-169. 